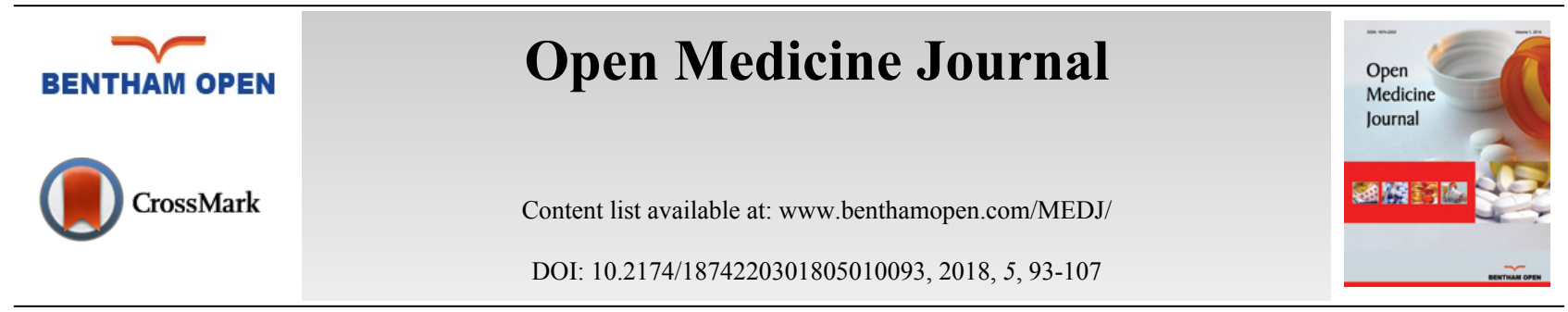

REVIEW ARTICLE

\title{
Oncoplastic Breast Surgery: A Review of Techniques Quadrant Per Quadrant
}

\author{
Gardani Marco ${ }^{1,2,}$, Bertozzi Nicolò ${ }^{2}$, Grieco Michele Pio $^{2}$, Pesce Marianna, ${ }^{3,4}$, Simonacci Francesco ${ }^{2}$, \\ Santi Pier Luigi, ${ }^{3,4}$ and Raposio Edoardo ${ }^{2}$ \\ ${ }^{I}$ Department of Surgery, Breast Unit, Guglielmo da Saliceto Hospital, Piacenza, Italy \\ ${ }^{2}$ Department of Medicine and Surgery, Plastic Surgery Division, University of Parma, Parma, Italy; Cutaneous, Mini- \\ invasive, Regenerative and Plastic Surgery Unit, Parma University Hospital, Parma, Italy \\ ${ }^{3}$ Department of Surgical Sciences and Integrated Diagnostics, University of Genoa, Genoa, Italy \\ ${ }^{4}$ Plastic Surgery Department, IRCCS San Martino University Hospital, National Institute for Cancer Research, Genoa, \\ Italy
}

Received: May 18, 2018

Revised: October 23, 2018

Accepted: November 14, 2018

\begin{abstract}
Breast Conserving Surgery (BCS) has gradually substituted mastectomy in the treatment of early-stage tumors. Indeed it ensures the same overall survival and better aesthetic results when followed post-operative radiotherapy. Nevertheless more than $20 \%$ excision of breast tissue, retro-areolar or lower pole cancer, and higer-sized breasts with ptosis, tend to result in aesthetically unpleasant results. Oncoplastic breast surgery finds its route into breast conserving surgery in the attempt to improve the aesthetic results while not compromising the oncologic ones.
\end{abstract}

Keywords: Reconstructive Surgery, Breast cancer, Breast conservative therapy, Oncoplastic breast surgery, Tumors, Post-operative radiotherapy.

\section{INTRODUCTION}

Breast Conserving Surgery (BCS) has gradually substituted mastectomy in the treatment of early-stage tumors. In association with radiation therapy, it ensures patients the same overall survival with an acceptable risk of local recurrence and better aesthetic results [1]. We usually make use of quadrantectomy in BCS to reduce the amount of tissue removed, to achieve complete removal of cancer, and to preserve breast shape [2].

The original description of quadrantectomy by Veronesi involved removal of a wide portion of skin and glandular parenchyma; the technique has gradually evolved into a more conservative procedure with reduced skin and glandular resection and a skin excision pattern oriented along the lines of tension, according to Langer and Kraissl [3, 4]. However, the standard technique is not associated with acceptable cosmetic outcomes when used with certain cancer sites (lower quadrant, upper pole, retroareolar quadrant). In addition, the volume of excised glandular parenchyma is an important predictor of breast deformity occurrence [5]. Indeed, a substantial risk of deformity is reported in the literature for cases in which more than $20 \%$ of the gland is removed [6]. In these cases, oncoplastic surgery consists of wide lumpectomy with filling of the lost tissue using different plastic surgery techniques. The goal is to improve the aesthetic results and greatly increase the indications for conservative treatment.

\footnotetext{
* Address correspondence to this author at the Department of Medicine and Surgery, Plastic Surgery Division, University of Parma, Parma, Italy, Cutaneous, Mini-invasive, Regenerative and Plastic Surgery Unit, Parma University Hospital, Parma, Italy, Tel: +393283027424; Fax: 0521-702041; E-mail: marco.gardani@hotmail.it
} 


\section{ONCOPLASTIC SURGERY}

The term oncoplastic, literally meaning "shaping the tumor", was first used by Gabka et al. [7] to describe plastic surgery techniques that expanded the indications for conservative breast cancer treatment. As affirmed at the Milanese Consensus Conference on Breast Conservation of 2006, Oncoplastic Breast Surgery (OBS) must aim for widely excised, clear margins without compromising the cosmetic result, and should be performed during the same operative time as oncological excision [8]. In the last several years, there has been increased use of these techniques due to both increased knowledge of the ideal breast size and the use of computer programs for preoperative breast reconstruction planning, including digital procedure simulations [9 - 11].

\section{PREOPERATIVE CONSIDERATIONS}

Before conservative oncoplastic surgery, several factors should be evaluated including the volume of the mammary gland to be removed, the site of the tumor, the size and density of the breast (a dense breast can be easily mobilized with less risk of necrosis than a less dense breast with a greater adipose component), the presence and/or degree of ptosis, and individual patient risk factors (obesity, smoking, diabetes, prior radiotherapy/chemotherapy). Patients who are affected by T4 tumors, multicentric cancer, extensive malignant microcalcifications, or inflammatory cancer are not eligible for BCS. These individuals require simple mastectomy followed by immediate or later reconstruction through tissue expansion $[12,13]$.

According to Clough et al. a two-level classification system based on excised tissue volume and cancer location can be used to identify the appropriate surgical technique [14]. If the removed tissue is less than $20 \%$, the level I technique should be used. This technique consists of the following steps: skin incision, cutaneous undermining (to ease cancer removal and subsequent glandular reshaping), detachment of Nipple-Areolar Complex (NAC), full thickness excision, defect closure by simple approximation of the margins, and any centralization of nipple areola complex [15]. If the removed tissue is greater than $20 \%$ or the breast is of high volume with severe ptosis, and if we are interested in the socalled hard-quadrant, we should choose a

level II technique. Level II is characterized by different oncoplastic techniques. Fig. (1a, b, c) According to the volume removed, the operated breast will be different than the contralateral. Therefore, the need for immediate or delayed contralateral symmetrization must be considered and discussed preoperatively [16].

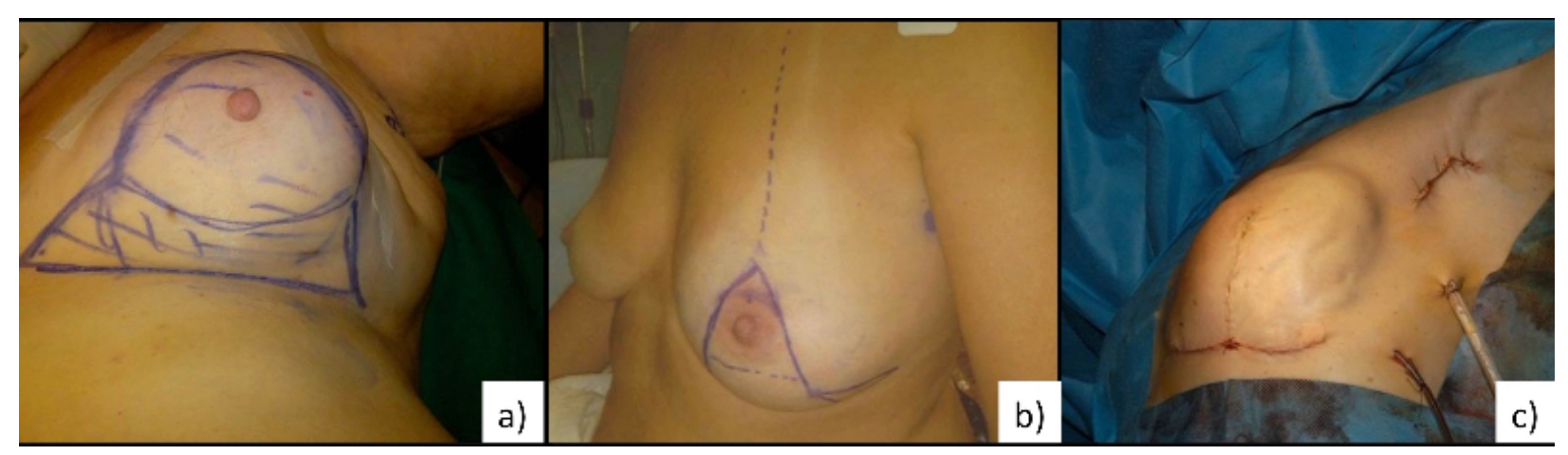

Fig. (1a, b). Inferior pedicle reduction mammoplasty technique with NAC excision for central breast cancer Preoperative drawnings. (c) Preoperative drawnings.

\section{SURGICAL TECHNIQUES}

These techniques can be broadly categorized as volume displacement, involving the principles of mobilization and transposition of local glandular (dermoglandular) flaps to fill surgical defects. Both Type I and II require volume displacement of residual glandular parenchyma, and they differ only in the volume of breast excised. For convenience in this discussion, we will divide the breast into quadrants and review the technical oncoplastic specifications for cancer in each. 


\section{LOWER QUADRANT (5-7 O' CLOCK)}

Several studies confirm the high risk of occurrence of major deformities in this quadrant [17 - 19], such as the turning down of the nipple areola complex or skin retraction. A superior pedicle mammoplasty allows oncoplastic surgeons to remove a large amount of tissue from the lower pole without causing the nipple areola complex displacement while improving the final breast shape. This technique results in inverted T- and periareolar scars [14]. The surgical technique begins with de-epithelialization of the area adjacent to the nipple-areola complex. The nipple areola complex is dissected away from the underlying breast tissue on a superior dermoglandular pedicle. The inframammary incision is then achieved, succeeded by wide undermining of the breast tissue from the pectoralis fascia. Undermining starts inferiorly and proceeds superiorly beneath the tumor, surrounding the medial and lateral aspects of the breast as well as the nipple-areola complex. The carcinoma is removed with an ample margin of normal breast tissue and overlying skin as determined by preoperative drawings. Once the resection is completed, the remodeling procedure involves opposing the two medial and lateral glandular columns in the midline to replace the defect and recentralization of the nipple areola complex $[14,20]$. Lejour and Lassus described a variant to this technique by a vertical- scar mammoplasty that avoids the submammary scar [21,22].

Additionally, Santanelli et al. proposed a variant of this technique to allow the removal of dependent tumors of the external-interior pendent quadrant [23].

\section{INFERIOR-INTERNAL QUADRANT (7-9 O' CLOCK)}

In these cases, it can be useful a V-mammoplasty technique, which requires a pyramidal section of the mammary gland, with the base located in the medial portion of the inframammary layer and its apex at the areola. This technique is characterized by a wide excision of an ample section of the lower inner quadrant en bloc with overlying skin. The reshaping of the remaining mammary gland is performed by medial advancement of the residual lower quadrants after cutting the submammary fold and completely undermining the lower pole. This mammoplasty leaves a $\mathrm{V}$ scar formed by the radial and inframammary incisions and a periareolar scar $[14,24]$

\section{UPPER- INNER QUADRANT (10-11 O'CLOCK)}

A BCS with abundant tissue removal may cause important alterations of the decollete. Silverstein et al. described a surgical technique that relies on the use of a preoperative type batwing design that allows the excision of large areas from this quadrant [25]. The batwing mammoplasty consists of a crescent-shaped central area of skin and gland adjoining two triangle-shape or wing-like areas of skin and gland extending from both sides of the nipple-areola complex. To perform this surgical technique, a batwing-shaped incision is drawn on the skin to surround the skin overlying the breast tumour. The lower half of the drawing should extend along the upper half of the areolar border. The upper central edge of the batwing incision will become the new superior areolar border. The glandular tissues cranial and caudal to the resection cavity are advanced together to replace the defect [26].

\section{UPPER QUADRANTS (11-1 O'CLOCK)/UPPER-PARACENTRAL QUADRANTS (12 O'CLOCK)}

To surgically approach these quadrants, it is advisable to use augmentation in the lower stalk with drawing/engraving preoperative according to Wise pattern excision. The preoperative drawings are equal to those described for the superior pedicle mammoplasty technique. The resection involves the upper pole. The inferior pedicle is de-epithelialized and advanced upwards towards the excision defect to achieve volume redistribution. Complementary resection is performed in the inner and outer lower quadrants to optimize breast silhouette [14] Figs. (2-9). Round block mammoplasty can also be used and will result in a periareolar scar as described by Benelli [27]. It is a simple technique where two concentric incisions are performed around the areola, followed by de- epithelialization inter-incisions skin and tumor excision. Finally, the gland is remodeled using medial and lateral glandular flaps and skin synthesis. 


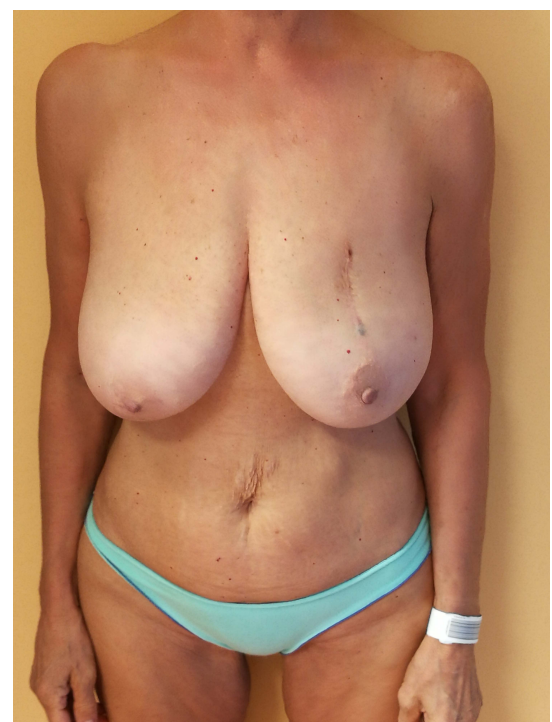

Fig. (2). Inferior pedicle reduction mammoplasty technique for left upper quadrant breast cancer - Preoperative photo.

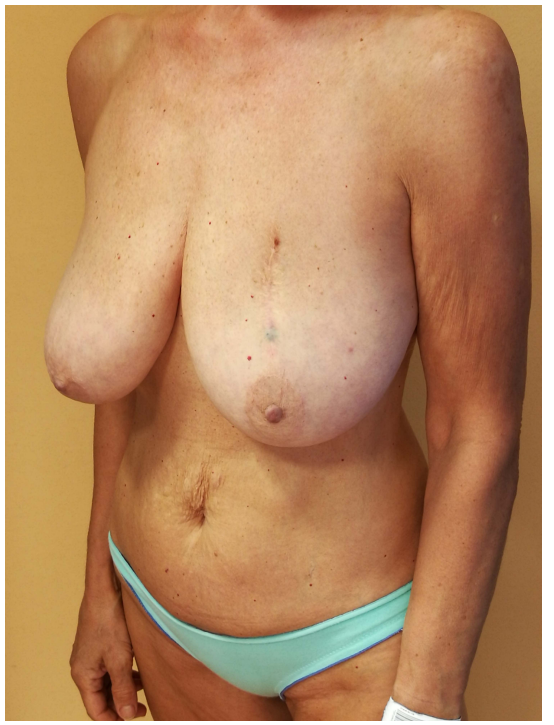

Fig. (3). Inferior pedicle reduction mammoplasty technique for left upper quadrant breast cancer - Preoperative photo.

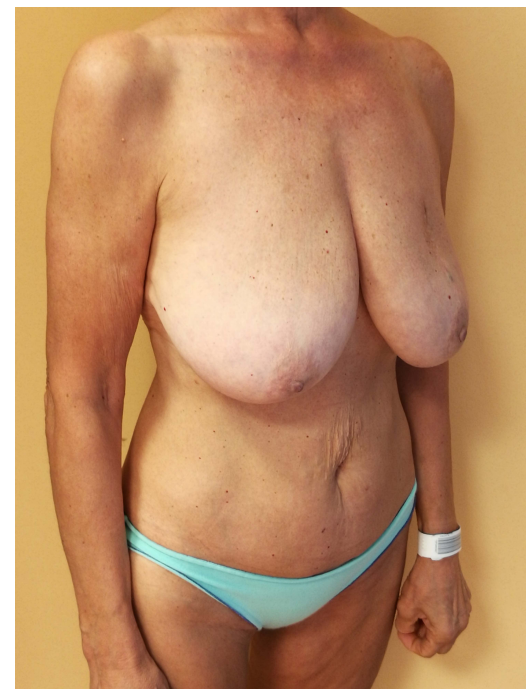

Fig. (4). Inferior pedicle reduction mammoplasty technique for left upper quadrant breast cancer - Preoperative photo. 


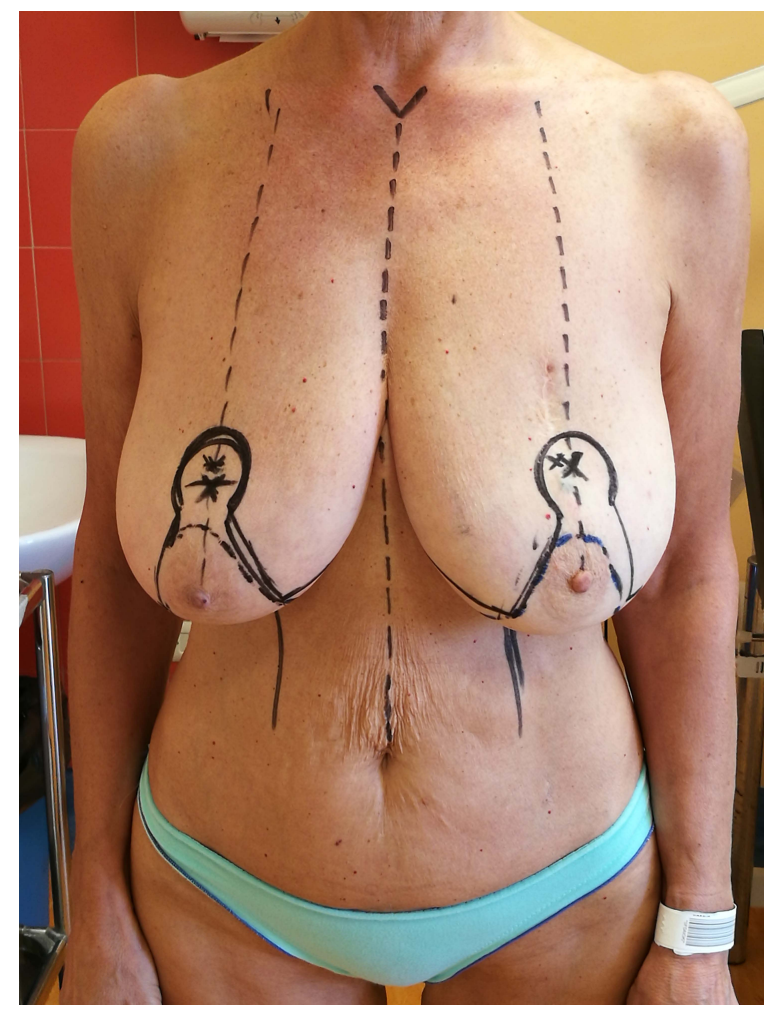

Fig. (5). Inferior pedicle reduction mammoplasty technique for left upper quadrant breast cancer - Preoperative photo.

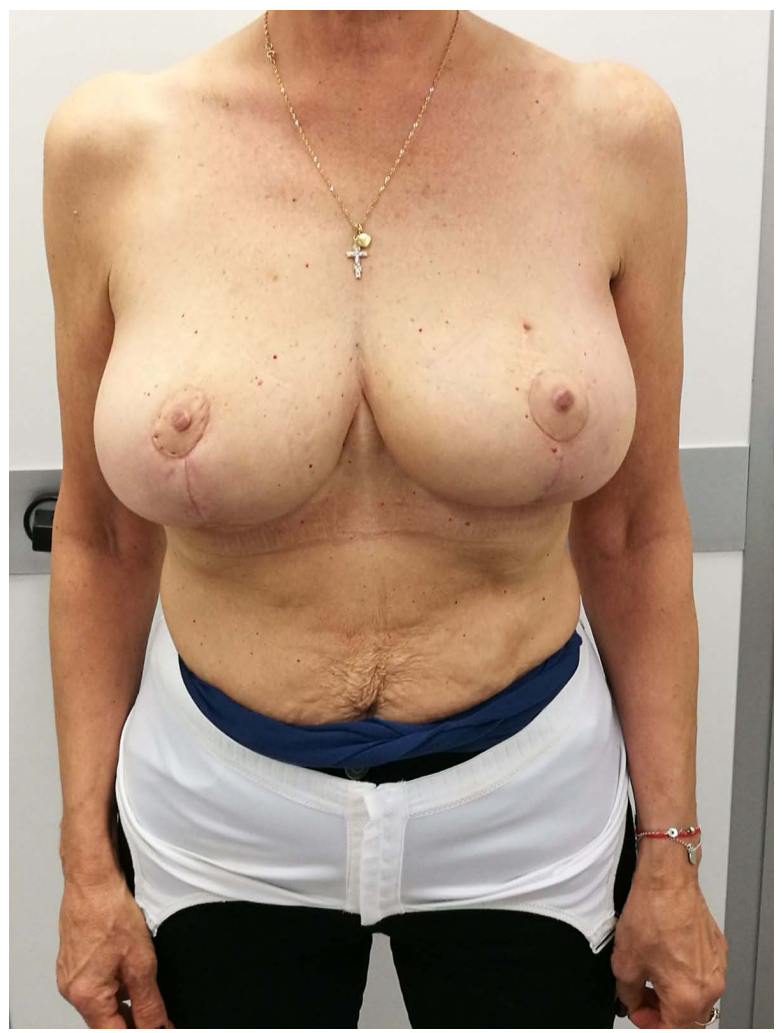

Fig. (6). Inferior pedicle reduction mammoplasty technique for left upper quadrant breast cancer Results at 14 days. 


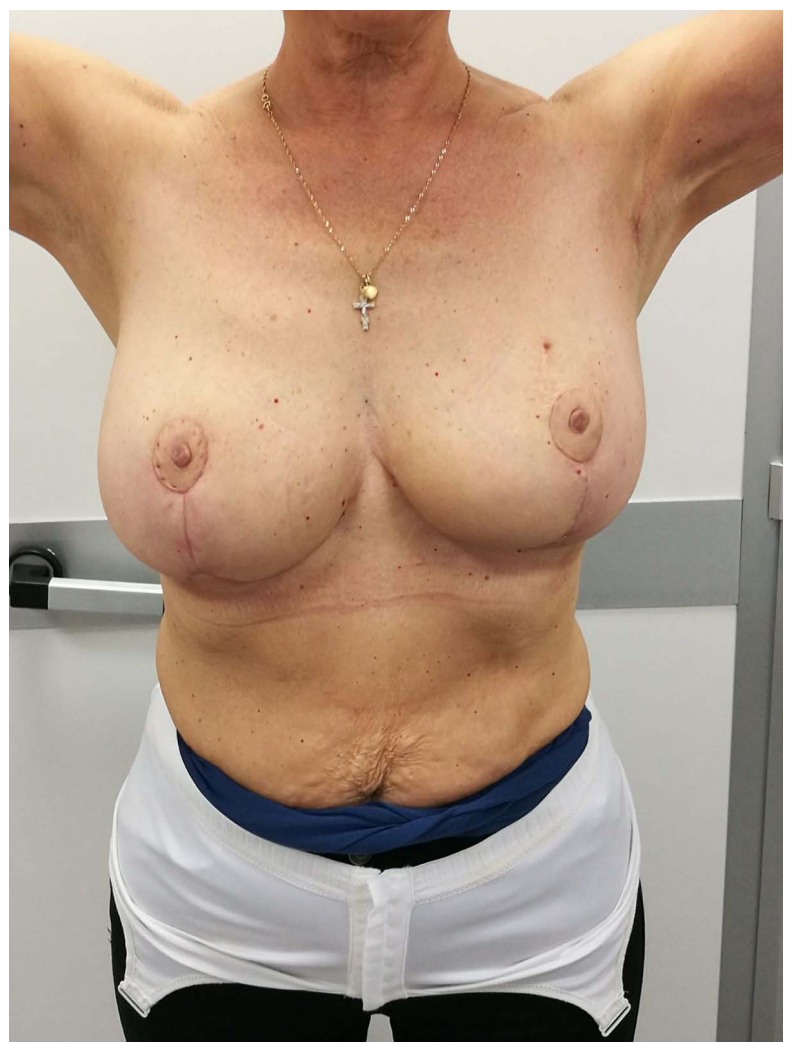

Fig. (7). Inferior pedicle reduction mammoplasty technique for left upper quadrant breast cancer - Results at 14 days.

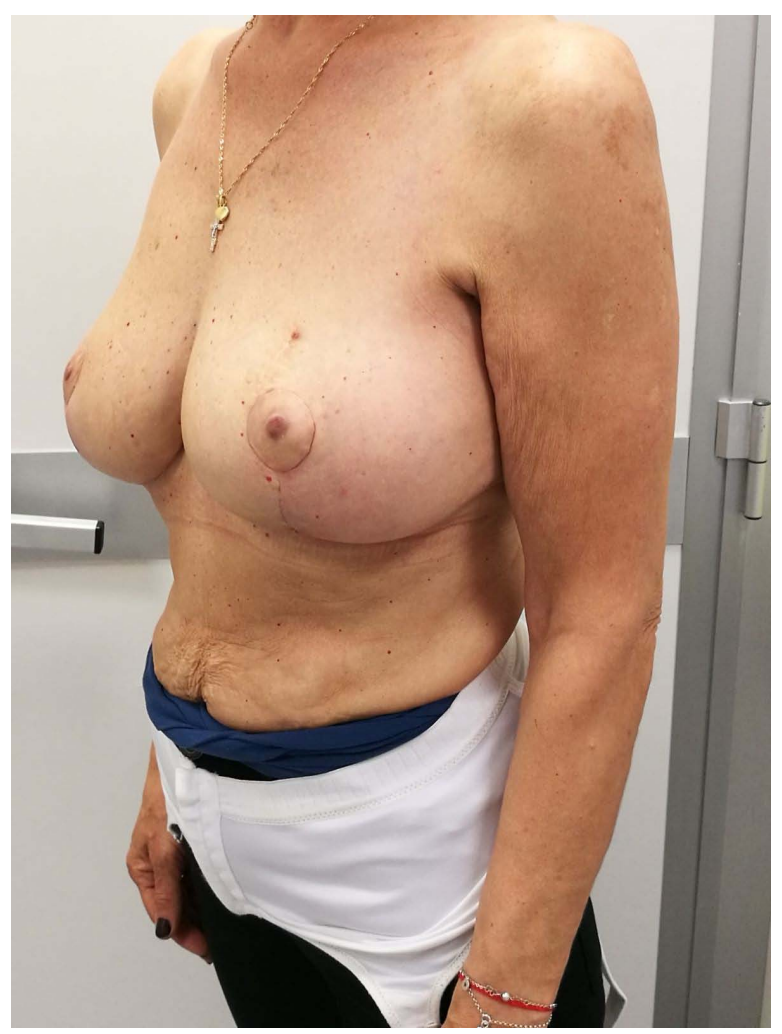

Fig. (8). Inferior pedicle reduction mammoplasty technique for left upper quadrant breast cancer - Results at 14 days. 


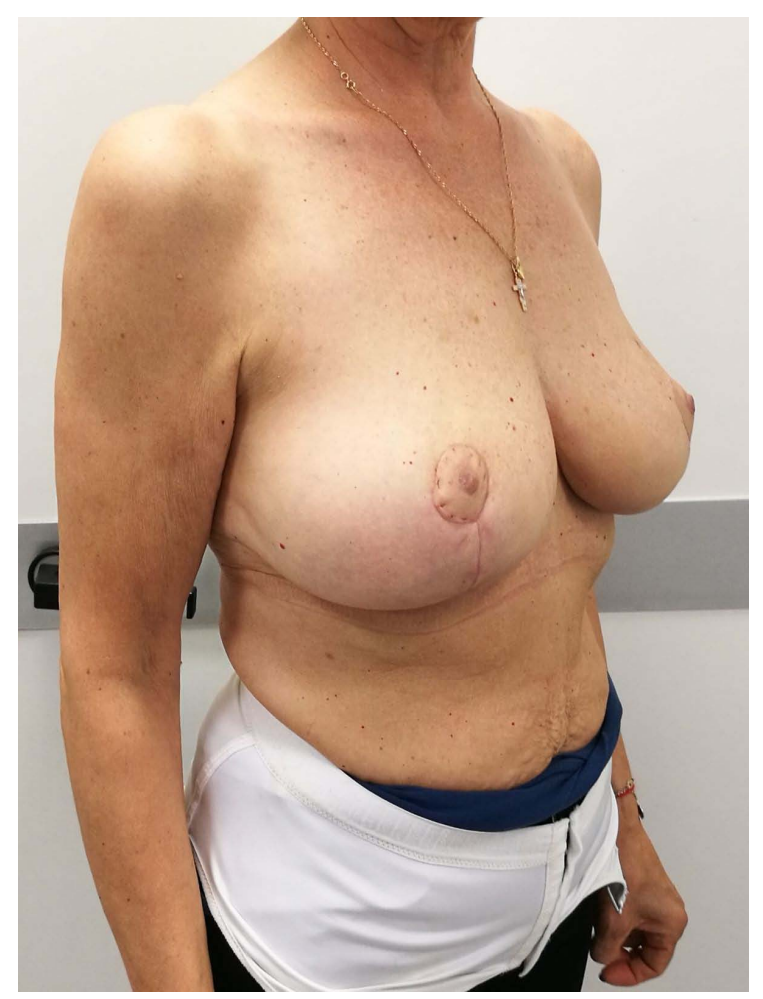

Fig. (9). Inferior pedicle reduction mammoplasty technique for left upper quadrant breast cancer - Results at 14 days.

\section{UPPER - OUTER QUADRANT (1-3 O' CLOCK)}

This quadrant can be described as the easiest to approach. In fact, bulky lesions may be excised using standard techniques of BCS without resulting in any breast deformity. Nevertheless, if more than $20 \%$ of breast tissue has to be removed, overlying skin may retract causing NAC migration toward ipsilateral axillary region Figs. (10-15). In this quadrant we can perform a racket mammoplasty which results in a radial cicatrix above the breast carcinoma location extending to the areola area, with repositioning of the nipple areola complex in the right site [14].

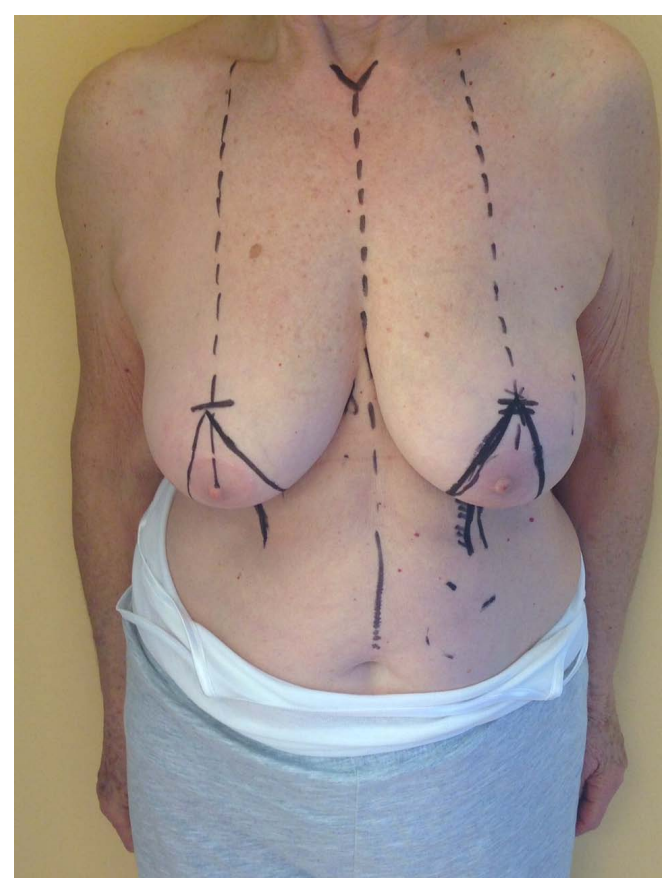

Fig. (10). Superior-medial pedicle reduction mammoplasty technique for left upper-outer quadrant breast cancer Preoperative photo. 


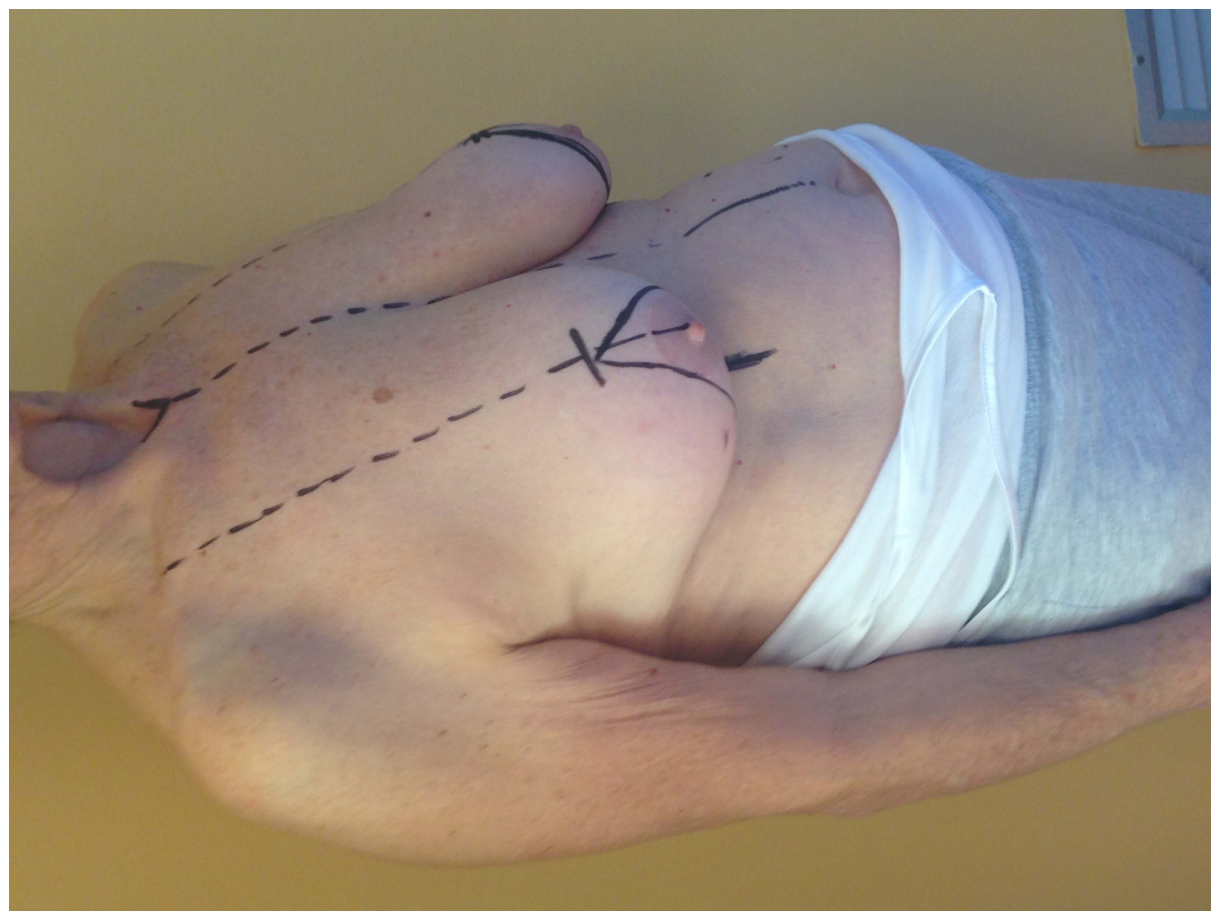

Fig. (11). Superior-medial pedicle reduction mammoplasty technique for left upper-outer quadrant breast cancer - Preoperative photo.

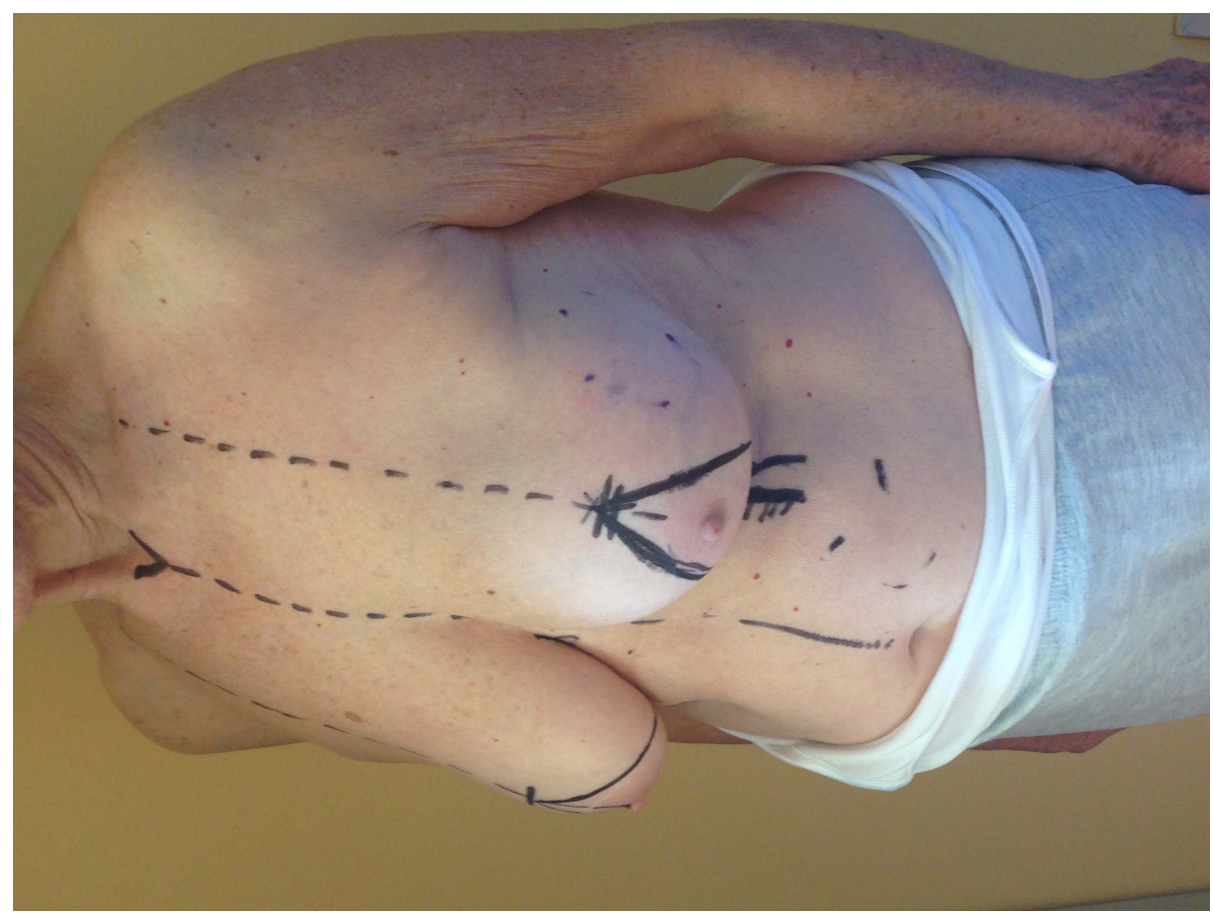

Fig. (12). Superior-medial pedicle reduction mammoplasty technique for left upper-outer quadrant breast cancer - Preoperative photo. 


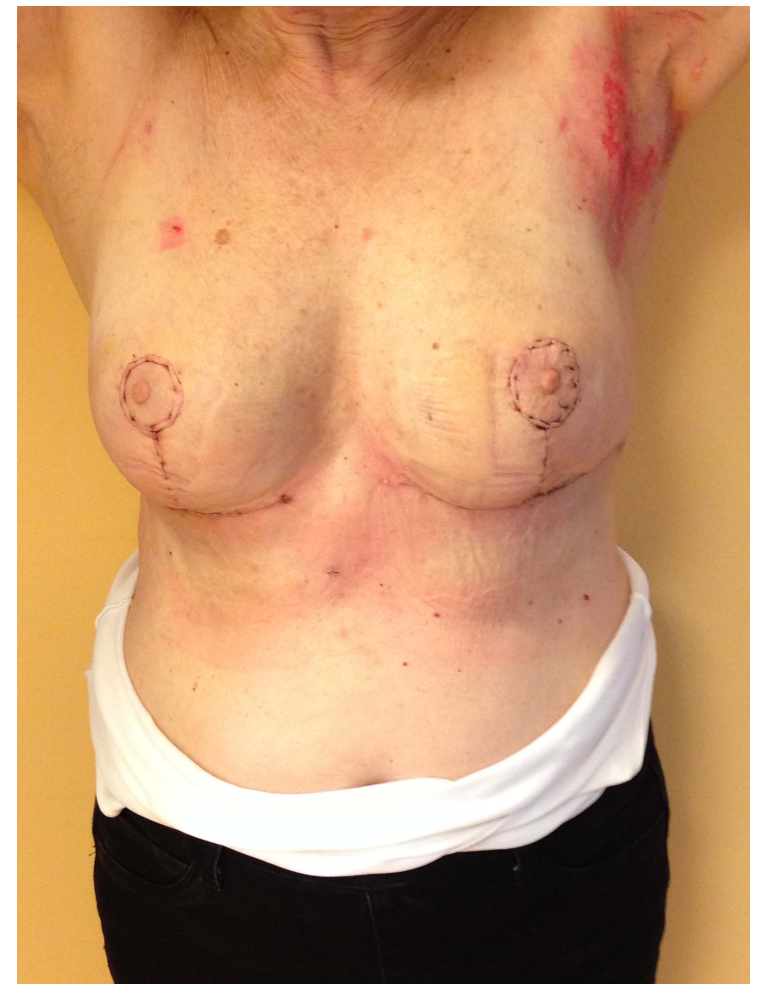

Fig. (13). Superior-medial pedicle reduction mammoplasty technique for left upper-outer quadrant breast cancer - Preoperative photo.

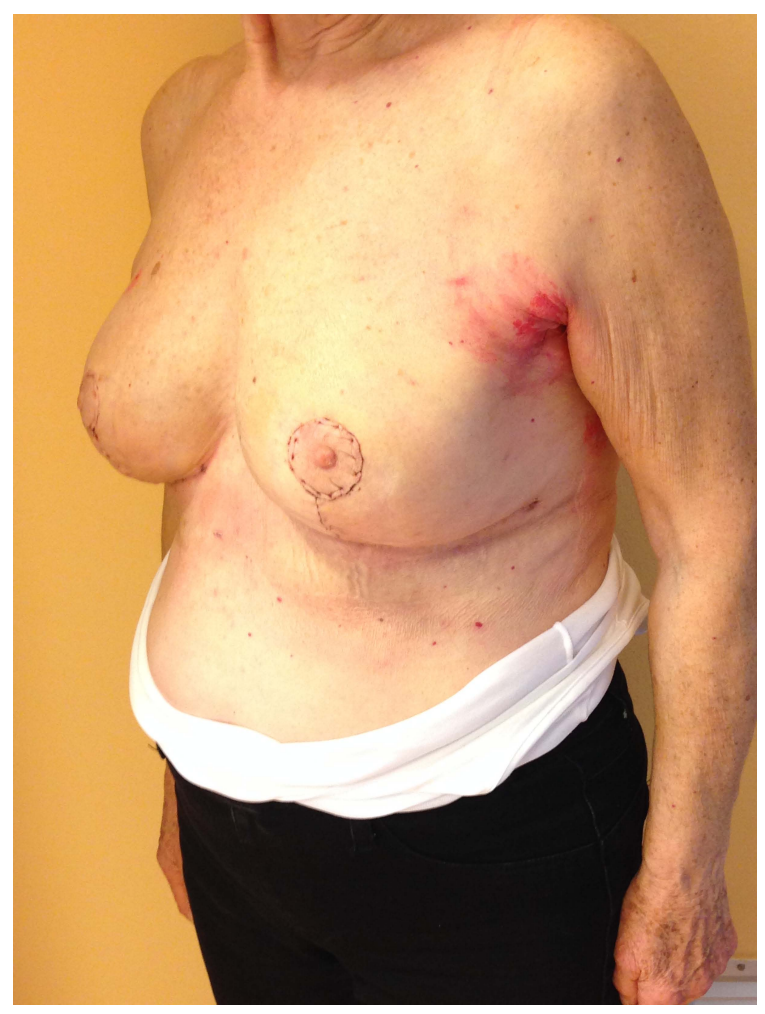

Fig. (14). Superior-medial pedicle reduction mammoplasty technique for left upper-outer quadrant breast cancer - Results at 7 days. 


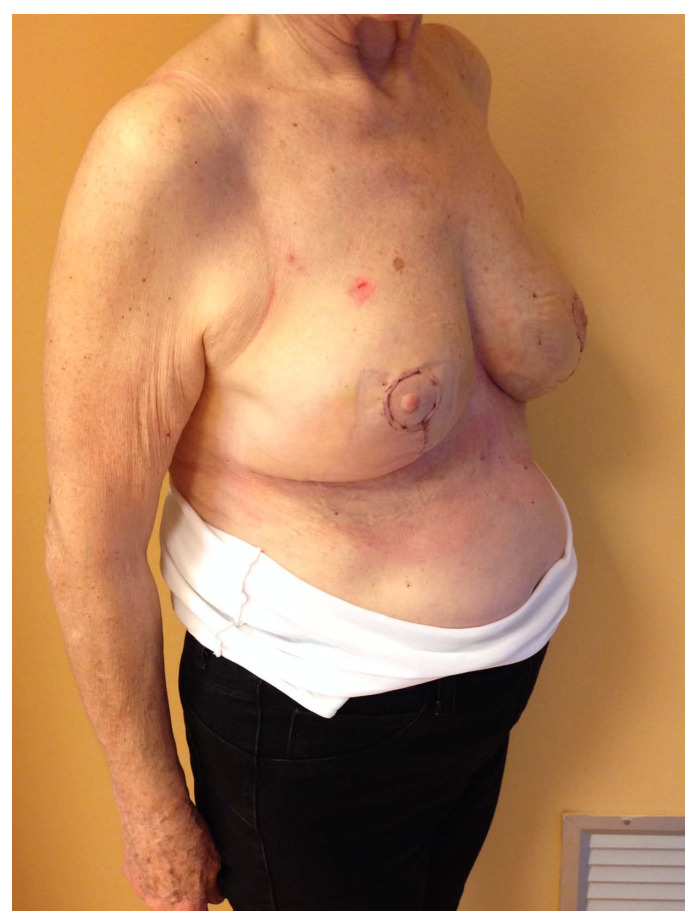

Fig. (15). Superior-medial pedicle reduction mammoplasty technique for left upper-outer quadrant breast cancer - Results at 7 days.

\section{LOWER- OUTER QUADRANT (4-5 O'CLOCK)}

The optimal procedure to approach this quadrant is a $\mathrm{J}$ - mammoplasty. The nipple areola complex is repositioned following the preoperative design of de-epithelialization in the upper stalk, and the mammary gland is excised in a manner which forms a letter "J". The remaining portions of the lateral and central gland are recruited to replace the defect [28].

\section{CENTRAL QUADRANTS}

We proceed with excision of the NAC and breast parenchyma affected by the tumor. If the patient has a glandular breast type, allowing a large dissection, we can use the techniques described for level I. If, instead, the breast has a predominant adipose tissue composition or if resection exceeds $20 \%$ of the total volume, we use advanced techniques with round-block type reconstruction or employ a Grisotti flap [29,30]. One possible interesting approach is to use the hemibatwing technique proposed by Pasta et al. [31]. This resection consists of a crescent-shaped area of NAC and gland, followed by a triangle-shaped or wing-like area over the adjoining skin and gland extended to one side of the areola. The surgery starts with an upper semicircular periareolar incision that is continued laterally toward the axilla. From the superior-medial side of the areola, the incision is extended to the inferior margin of the areola and then halfway around the NAC circumference. Finally, the incision is extended linearly onto the lateral external quadrant, according to the position of the lesion.

\section{SECONDARY PROCEDURE}

Nipple-Areola-Complex (NAC) reconstruction and Autologous Fat Grafting (AFG) can be both performed secondary to oncoplastic breast surgery techniques to ameliorate the postoperative cosmetic outcome. If the NAC has to be excised along with the breast cancer, numerous local flaps are available for its reconstruction and can be performed starting from the 2nd postoperative month; NAC tattooing has to be delayed for further 6 weeks following NAC reconstruction [32].

Residual contour deformities and asymmetry with contralateral breast can improve by the use of AFG [33]. Indeed autologous fat graft is the ideal filler by being of the same patient [34]. Furthermore, its function is more than simply filling a defect but can improve the texture of the skin, scars and any late chronic degenerative side effect of radiation 
therapy [35]. AFG owes its regenerative and therapeutic properties to the presence of the Adipose-derived Stem Cells (ASCs):

a population of multipotent mesenchymal stem cells that show definitive stem cell characteristics such as plastic adherence in culture, ability to maintain multipotency upon in vitro expansion, and self-renewal capacity [36 - 41]. ASCs can be isolated from the harvested adipose tissue by either mechanical or enzymatic means and eventually grafted together with the processed lipoaspirates [42 - 46]. ASCs can differentiate into multiple cell lineages and secrete paracrine factors;

hence promoting angiogenesis and wound healing, leading to higher fat graft survival as well as dermal and subcutaneous tissue regeneration [34, 42, 47 - 49].

Furthermore, contralateral matching surgeries can be performed at the time of the oncoplastic surgery or whenever the patient may feel requiring it [12]. Mastopexy, reductive or augmentation mastoplasties are all available techniques that every breast surgeon should be able to master easily. These procedures bring with them further potential complications (i.e., seroma, infection, suture dehiscence, flap necrosis, implant exposures, asymmetry) but are also capable of improving greatly the cosmetic outcome reducing the psychological impact that oncologic breast surgeries have on women $[6,7,25,50]$. Therefore, contralateral matching surgeries should always be encouraged and performed at the time of the oncoplastic surgery in order to reduce the feeling of mutilation.

\section{COMPLICATIONS OF ONCOPLASTIC BREAST SURGERY}

According to a recent paper published by Losken et al. the complication rate with oncoplastic surgery techniques is around $16 \%$ [50]. Complications may be divided into two groups. First, there are the so-called early complications, such as delayed healing, hematoma, seroma, abscess, skin or NAC necrosis. The second group describes the late complications, including fibrosis of the scar, keloids and steatonecrosis [51]. One major complication is necrosis of the glandular breast tissue, due primarily to the mobilization of significant amounts of tissue. This it can happen especially in large-sized breast, with low gland/adipose tissure rate where breast have to be extensively dissected from the underlying muscular floor. Secondary infection of the necrotic areas may worsen the situation, resulting in increased postoperative morbidity and delayed adjuvant cancer therapies. Preoperative antibiotic prophylaxis is very important in minimizing the occurrence of these complications, and may be extended in the following day on case to case basis [52]. Furthermore, preoperative planning can benefit from new computer devices [53]. A rational approach is needed to enable surgeons to act preventively on individual risk factors (obesity, smoking, diabetes, thyroid disorders, hypertension) to lower complication rate in the postoperative period, as these factors are recognized as independently significant for the development of complications [54 - 56]

\section{ONCOLOGICAL SAFETY}

Regardless of the surgical technique used, adjuvant radiation therapy is mandatory, with several studies confirming a significant reduction in local recurrence with the advantage of better oncological results compared to the use of surgery alone [57].

A systematic review of studies of oncoplastic breast-conserving surgery demonstrated higher rates of complications with no impact on adjuvant therapies timing and oncological outcomes [58]. It has been shown that oncoplastic techniques, in addition to ensuring a more effective surgery, can provide effective radiation treatment planning. Additionally, patients with large breasts who undergo breast reductive techniques require lower doses of radiation than those treated with standard techniques [59 - 61].

\section{CONCLUSION}

We can then consider oncoplastic breast surgery a fundamental tool in the multidisciplinary approach to breast cancer treatment. Indeed large amount of breast tissue can be safely excised without resulting in poor cosmetic outcomes. Furthermore patient satisfaction rates highly improved while esnuring oncological safety and potentially reducing the number of re-excision and mastectomy. Possible disadvantages are long operating times and frequent need to operate on the contralateral breast in order to achieve satisfactory bilateral symmetry.

Furthermore, new prospective observational studies are needed to assess possible long-term complications of such techniques. 


\section{CONSENT FOR PUBLICATION}

Not applicable.

\section{CONFLICT OF INTEREST}

There is no conflict of interest, financial or otherwise.

\section{ACKNOWLEDGEMENTS}

Declared none.

\section{REFERENCES}

[1] Veronesi U, Cascinelli N, Mariani L, et al. Twenty-year follow-up of a randomized study comparing breast-conserving surgery with radical mastectomy for early breast cancer. N Engl J Med 2002; 347(16): 1227-32. [http://dx.doi.org/10.1056/NEJMoa020989] [PMID: 12393819]

[2] Veronesi U, Del Vecchio M, Luini A, Rasponi A, Zucali R. The quadrantectomy, axillary dissection and radiotherapy (QU.A.RT) technique in early breast cancer. Int Adv Surg Oncol 1983; 6: 141-65.

[PMID: 6874082]

[3] Gibson T. Karl langer (1819-1887) and his lines. Br J Plast Surg 1978; 31(1): 1-2. [http://dx.doi.org/10.1016/0007-1226(78)90002-4] [PMID: 342024]

[4] Kraissl CJ. The selection of appropriate lines for elective surgical incisions. Plast Reconstr Surg (1946) 1951; 8(1): 1-28. [http://dx.doi.org/10.1097/00006534-195107000-00001] [PMID: 14864071]

[5] Clough KB, Kaufman GJ, Nos C, Buccimazza I, Sarfati IM. Improving breast cancer surgery: A classification and quadrant per quadrant atlas for oncoplastic surgery. Ann Surg Oncol 2010; 17(5): 1375-91 [http://dx.doi.org/10.1245/s10434-009-0792-y] [PMID: 20140531]

[6] Bulstrode NW, Shrotria S. Prediction of cosmetic outcome following conservative breast surgery using breast volume measurements. Breast 2001; 10(2): 124-6. [http://dx.doi.org/10.1054/brst.2000.0197] [PMID: 14965571]

[7] Gabka CJ, Maiwald G, Baumeister RG. Expanding the indications spectrum for breast saving therapy of breast carcinoma by oncoplastic operations. Langenbecks Arch Chir Suppl Kongressbd 1997; 114: 1224-7. [PMID: 9574385]

[8] Schwartz GF, Veronesi U, Clough KB, et al. Consensus conference on breast conservation. J Am Coll Surg 2006 ; $203(2)$ : $198-207$. [http://dx.doi.org/10.1016/j.jamcollsurg.2006.04.009] [PMID: 16864033]

[9] Raposio E, Belgrano V, Santi P, Chiorri C. Which is the ideal ireast iize?: Some social clues for plastic surgeons. Ann Plast Surg 2016; 76(3): 340-5.

[http://dx.doi.org/10.1097/SAP.0000000000000471] [PMID: 25664414]

[10] Raposio E, Cicchetti S, Adami M, Ciliberti RG, Santi PL. Computer planning for breast reconstruction by tissue expansion: An update. Plast Reconstr Surg 2004; 113(7): 2095-7. [http://dx.doi.org/10.1097/01.PRS.0000121189.51406.12] [PMID: 15253203]

[11] Raposio E, Caregnato P, Barabino P, et al. Computer-based preoperative planning for breast reconstruction in the woman with unilateral breast hypoplasia. Minerva Chir 2002; 57(5): 711-4.

[PMID: 12370677]

[12] Oncoplastic breast surgery-a guide to good practice. Eur J Surg Oncol 2007; 33: 1-23. [http://dx.doi.org/10.1016/j.ejso.2007.04.014] [PMID: 17126522]

[13] Fan J, Raposio E, Wang J, Nordström RE. Development of the inframammary fold and ptosis in breast reconstruction with textured tissue expanders. Aesthetic Plast Surg 2002; 26(3): 219-22. [http://dx.doi.org/10.1007/s00266-002-1477-0] [PMID: 12140704]

[14] Clough KB, Kaufman GJ, Nos C, Buccimazza I, Sarfati IM. Improving breast cancer surgery: A classification and quadrant per quadrant atlas for oncoplastic surgery. Ann Surg Oncol 2010; 17(5): 1375-91. [http://dx.doi.org/10.1245/s10434-009-0792-y] [PMID: 20140531]

[15] Mansfield L, Agrawal A, Cutress RI. Oncoplastic breast conserving surgery. Gland Surg 2013; 2(3): $158-62$. [PMID: 25083477]

[16] Kronowitz SJ, Hunt KK, Kuerer HM, et al. Practical guidelines for repair of partial mastectomy defects using the breast reduction technique in patients undergoing breast conservation therapy. Plast Reconstr Surg 2007; 120(7): 1755-68. [http://dx.doi.org/10.1097/01.prs.0000287130.77835.f6] [PMID: 18090737]

[17] Clough KB, Nos C, Salmon RJ, Soussaline M, Durand JC. Conservative treatment of breast cancers by mammaplasty and irradiation: A new approach to lower quadrant tumors. Plast Reconstr Surg 1995; 96(2): 363-70. [http://dx.doi.org/10.1097/00006534-199508000-00015] [PMID: 7624409] 
[18] Clough KB, Soussaline M, Campana F, Salmon RJ. Mammoplasty combined with irradiation: Conservative treatment of breast cancer localized in the lower quadrant. Ann Chir Plast Esthet 1990; 35(2): 117-22. [PMID: 1696083]

[19] Nos C, Fitoussi A, Bourgeois D, Fourquet A, Salmon RJ, Clough KB. Conservative treatment of lower pole breast cancers by bilateral mammoplasty and radiotherapy. Eur J Surg Oncol 1998; 24(6): 508-14. [http://dx.doi.org/10.1016/S0748-7983(98)93356-X] [PMID: 9870725]

[20] Clough KB, Lewis JS, Couturaud B, Fitoussi A, Nos C, Falcou MC. Oncoplastic techniques allow extensive resections for breast-conserving therapy of breast carcinomas. Ann Surg 2003; 237(1): 26-34.

[http://dx.doi.org/10.1097/00000658-200301000-00005] [PMID: 12496527]

[21] Lejour M, Abboud M, Declety A, Kertesz P. Reduction of mammaplasty scars: From a short inframammary scar to a vertical scar. Ann Chir Plast Esthet 1990; 35(5): 369-79. [PMID: 1712564]

[22] Lassus C. A 30-year experience with vertical mammaplasty. Plast Reconstr Surg 1996; 97(2): 373-80. [http://dx.doi.org/10.1097/00006534-199602000-00015] [PMID: 8559820]

[23] Santanelli F, Paolini G, Campanale A, Longo B, Amanti C. Modified Wise-pattern reduction mammaplasty, a new tool for upper quadrantectomies: A preliminary report. Ann Surg Oncol 2009; 16(5): 1122-7. [http://dx.doi.org/10.1245/s10434-009-0358-z] [PMID: 19255809]

[24] Clough KB, Oden S, Ihrai T, Massey E, Nos C, Sarfati I. Level 2 oncoplastic surgery for lower inner quadrant breast cancers: The LIQ-V mammoplasty. Ann Surg Oncol 2013; 20(12): 3847-54.

[http://dx.doi.org/10.1245/s10434-013-3085-4] [PMID: 23838910]

[25] Anderson BO, Masetti R, Silverstein MJ. Oncoplastic approaches to partial mastectomy: An overview of volume-displacement techniques. Lancet Oncol 2005; 6(3): 145-57. [http://dx.doi.org/10.1016/S1470-2045(05)01765-1] [PMID: 15737831]

[26] Holmes DR, Schooler W, Smith R. Oncoplastic approaches to breast conservation. Int J Breast Cancer 2011; $2011: 303879$. [http://dx.doi.org/10.4061/2011/303879] [PMID: 22295216]

[27] Benelli L. A new periareolar mammaplasty: The "round block" technique. Aesthetic Plast Surg 1990; 14(2): 93-100 [http://dx.doi.org/10.1007/BF01578332] [PMID: 2185619]

[28] Gasperoni C, Salgarello M, Gasperoni P. A personal technique: Mammaplasty with J scar. Ann Plast Surg 2002; 48(2): 124-30. [http://dx.doi.org/10.1097/00000637-200202000-00002] [PMID: 11910216]

[29] Della Rovere GQ, Pillarisetti RR, Bonomi R, Benson J. Oncoplastic surgery for retro areolar breast cancer - a technical modification of the grisotti flap. Indian J Surg 2007; 69(4): 160-2. [http://dx.doi.org/10.1007/s12262-007-0012-6] [PMID: 23132973]

[30] Galimberti V, Zurrida S, Zanini V, et al. Central small size breast cancer: how to overcome the problem of nipple and areola involvement. Eur J Cancer 1993; 29A(8): 1093-6. [http://dx.doi.org/10.1016/S0959-8049(05)80294-1] [PMID: 8518018]

[31] Pasta V, D’Orazi V, Merola R, et al. Oncoplastic central quadrantectomies. Gland Surg 2016; 5(4): 422-6 [http://dx.doi.org/10.21037/gs.2016.04.01] [PMID: 27563564]

[32] Farhadi J, Maksvytyte GK, Schaefer DJ, Pierer G, Scheufler O. Reconstruction of the nipple-areola complex: An update. J Plast Reconstr Aesthet Surg 2006; 59(1): 40-53. [http://dx.doi.org/10.1016/j.bjps.2005.08.006] [PMID: 16482789]

[33] Simonacci F, Bertozzi N, Grieco MP, Grignaffini E, Raposio E. Procedure, applications, and outcomes of autologous fat grafting. Ann Med Surg (Lond) 2017; 20: 49-60.

[http://dx.doi.org/10.1016/j.amsu.2017.06.059] [PMID: 28702187]

[34] Simonacci F, Bertozzi N, Grieco MP, Grignaffini E, Raposio E. Autologous fat transplantation for breast reconstruction: A literature review. Ann Med Surg (Lond) 2016; 12: 94-100. [http://dx.doi.org/10.1016/j.amsu.2016.11.012] [PMID: 27942383]

[35] Rigotti G, Marchi A, Galiè M, et al. Clinical treatment of radiotherapy tissue damage by lipoaspirate transplant: A healing process mediated by adipose-derived adult stem cells. Plast Reconstr Surg 2007; 119(5): 1409-22. [http://dx.doi.org/10.1097/01.prs.0000256047.47909.71] [PMID: 17415234]

[36] Scanarotti C, Bassi AM, Catalano M, et al. Neurogenic-committed human pre-adipocytes express CYP1A isoforms. Chem Biol Interact 2010; 184(3): 474-83.

[http://dx.doi.org/10.1016/j.cbi.2010.01.009] [PMID: 20080079]

[37] Raposio E, Guida C, Baldelli I, et al. Characterization and induction of human pre-adipocytes. Toxicol In Vitro 2007; 21(2): 330-4. [http://dx.doi.org/10.1016/j.tiv.2006.09.022] [PMID: 17113745]

[38] Coradeghini R, Guida C, Scanarotti C, et al. A comparative study of proliferation and hepatic differentiation of human adipose-derived stem cells. Cells Tissues Organs (Print) 2010; 191(6): 466-77. [http://dx.doi.org/10.1159/000273266] [PMID: 20051678] 
[39] Aluigi MG, Coradeghini R, Guida C, et al. Pre-adipocytes commitment to neurogenesis 1: Preliminary localisation of cholinergic molecules. Cell Biol Int 2009; 33(5): 594-601. [http://dx.doi.org/10.1016/j.cellbi.2009.02.014] [PMID: 19286468]

[40] Raposio E, Guida C, Coradeghini R, et al. In vitro polydeoxyribonucleotide effects on human pre-adipocytes. Cell Prolif 2008; 41 (5): 739-54. [http://dx.doi.org/10.1111/j.1365-2184.2008.00547.x] [PMID: 18673371]

[41] Bertozzi N, Simonacci F, Grieco MP, Grignaffini E, Raposio E. The biological and clinical basis for the use of adipose-derived stem cells in the field of wound healing. Ann Med Surg (Lond) 2017; 20: 41-8. [http://dx.doi.org/10.1016/j.amsu.2017.06.058] [PMID: 28702186]

[42] Raposio E, Bertozzi N. Isolation of ready-to-use Adipose-derived Stem Cell (ASC) pellet for clinical applications and a comparative overview of alternate methods for ASC isolation. Curr Protoc Stem Cell Biol 2017; 16(41) 1F.17.1-1F.17

[43] Raposio E, Bonomini S, Calderazzi F. Isolation of autologous adipose tissue-derived mesenchymal stem cells for bone repair. Orthop Traumatol Surg Res 2016; 102(7): 909-12. [http://dx.doi.org/10.1016/j.otsr.2016.07.006] [PMID: 27638160]

[44] Raposio E, Caruana G, Bonomini S, Libondi G. A novel and effective strategy for the isolation of adipose-derived stem cells: Minimally manipulated adipose-derived stem cells for more rapid and safe stem cell therapy. Plast Reconstr Surg 2014; 133(6): 1406-9. [PMID: 24867723]

[45] Raposio E, Caruana G, Petrella M, Bonomini S, Grieco MP. A standardized method of isolating adipose-derived stem cells for clinical applications. Ann Plast Surg 2016; 76(1): 124-6. [http://dx.doi.org/10.1097/SAP.0000000000000609] [PMID: 26418805]

[46] Fisher C, Grahovac TL, Schafer ME, Shippert RD, Marra KG, Rubin JP. Comparison of harvest and processing techniques for fat grafting and adipose stem cell isolation. Plast Reconstr Surg 2013; 132(2): 351-61. [http://dx.doi.org/10.1097/PRS.0b013e3182958796] [PMID: 23584621]

[47] Caruana G, Bertozzi N, Boschi E, Pio Grieco M, Grignaffini E, Raposio E. Role of adipose-derived stem cells in chronic cutaneous wound healing. Ann Ital Chir 2015; 86(1): 1-4. [PMID: 25818696]

[48] Raposio E, Bertozzi N, Bonomini S, et al. Adipose-derived stem cells added to platelet-rich plasma for chronic skin ulcer therapy. Wounds 2016; 28(4): 126-31. [PMID: 27071140]

[49] Raposio E, Calderazzi F. Fat grafting for chronic heel pain following surgery for adult flatfoot deformity: Pilot study. Foot 2017; 31 : 56-60. [http://dx.doi.org/10.1016/j.foot.2017.02.005] [PMID: 28549282]

[50] Losken A, Dugal CS, Styblo TM, Carlson GW. A meta-analysis comparing breast conservation therapy alone to the oncoplastic technique. Ann Plast Surg 2014; 72(2): 145-9. [http://dx.doi.org/10.1097/SAP.0b013e3182605598] [PMID: 23503430]

[51] Staub G, Fitoussi A, Falcou MC, Salmon RJ. Breast cancer surgery: Use of mammaplasty. Results. Series of 298 cases. Ann Chir Plast Esthet 2008; 53(2): 124-34. [http://dx.doi.org/10.1016/j.anplas.2007.05.012] [PMID: 17949880]

[52] Shortt R, Cooper MJ, Farrokhyar F, Bain J. Meta-analysis of antibiotic prophylaxis in breast reduction surgery. Plast Surg (Oakv) 2014; 22(2): $91-4$ [http://dx.doi.org/10.1177/229255031402200211] [PMID: 25114620]

[53] Porro I, Schenone A, Fato M, Raposio E, Molinari E, Beltrame F. An integrated environment for plastic surgery support: Building virtual patients, simulating interventions, and supporting intraoperative decisions. Comput Med Imaging Graph 2005; 29(5): 385-94. [http://dx.doi.org/10.1016/j.compmedimag.2005.02.005] [PMID: 15893913]

[54] Pluvy I, Panouillères M, Garrido I, et al. Smoking and plastic surgery, part II. Clinical implications: A systematic review with meta-analysis. Ann Chir Plast Esthet 2015; 60(1): e15-49. [http://dx.doi.org/10.1016/j.anplas.2014.09.011] [PMID: 25447218]

[55] Xue DQ, Qian C, Yang L, Wang XF. Risk factors for surgical site infections after breast surgery: A systematic review and meta-analysis. Eur J Surg Oncol 2012; 38(5): 375-81. [http://dx.doi.org/10.1016/j.ejso.2012.02.179] [PMID: 22421530]

[56] Hart A, Funderburk CD, Chu CK, et al. The impact of diabetes mellitus on wound healing in breast reconstruction. Ann Plast Surg 2017; 78(3): 260-3.

[http://dx.doi.org/10.1097/SAP.0000000000000881] [PMID: 27505449]

[57] Vinh-Hung V, Verschraegen C. Breast-conserving surgery with or without radiotherapy: Pooled-analysis for risks of ipsilateral breast tumor recurrence and mortality. J Natl Cancer Inst 2004; 96(2): 115-21. [http://dx.doi.org/10.1093/jnci/djh013] [PMID: 14734701]

[58] McIntosh J, O’Donoghue JM. Therapeutic mammaplasty-a systematic review of the evidence. Eur J Surg Oncol 2012; 38(3): 196-202. [http://dx.doi.org/10.1016/j.ejso.2011.12.004] [PMID: 22206704] 
[59] Clough KB, Lewis JS, Couturaud B, Fitoussi A, Nos C, Falcou MC. Oncoplastic techniques allow extensive resections for breast-conserving therapy of breast carcinomas. Ann Surg 2003; 237(1): 26-34. [http://dx.doi.org/10.1097/00000658-200301000-00005] [PMID: 12496527]

[60] Veronesi U, Marubini E, Mariani L, et al. Radiotherapy after breast-conserving surgery in small breast carcinoma: Long-term results of a randomized trial. Ann Oncol 2001; 12(7): 997-1003. [http://dx.doi.org/10.1023/A:1011136326943] [PMID: 11521809]

[61] Clarke M, Collins R, Darby S, et al. Effects of radiotherapy and of differences in the extent of surgery for early breast cancer on local recurrence and 15-year survival: An overview of the randomised trials. Lancet 2005; 366(9503): 2087-106. [http://dx.doi.org/10.1016/S0140-6736(05)67887-7] [PMID: 16360786]

\section{(C) 2018 Marco et al.}

This is an open access article distributed under the terms of the Creative Commons Attribution 4.0 International Public License (CC-BY 4.0), a copy of which is available at: https://creativecommons.org/licenses/by/4.0/legalcode. This license permits unrestricted use, distribution, and reproduction in any medium, provided the original author and source are credited. 